\title{
Infant mortality and prenatal care: contributions of the clinic in the light of Canguilhem and Foucault
}

\author{
Paula Pereira de Figueiredo ${ }^{1}$ \\ Wilson Danilo Lunardi Filho \\ Valéria Lerch Lunardi² \\ Fernanda Demutti Pimpão ${ }^{3}$
}

This review study aimed to verify how studies conducted in Brazil have related infant mortality to prenatal care and to present contributions of the clinic in the light of Canguilhem and Foucault for qualification of the care. An integrative literature review was conducted from searches in the databases SciELO, LILACS, MEDLINE and BDENF for the period 2000 to 2009. The relationship between infant mortality and prenatal care is related to the insufficient number of consultations or to the quality of the care provided. Even when the number of and routine consultations in the prenatal care were adequate, avoidable deaths were present. For the qualification of prenatal care, it is suggested that the clinical knowledge and other elements that comprise the process of human living are considered, in order that the clinical view is enlarged and articulated to the technologies available in the health system and, together, they are able to contribute to the reduction of infant mortality in Brazil.

Descriptors: Infant Mortality; Prenatal Care; Clinical Competence; Nursing.

\footnotetext{
${ }^{1}$ RN, Doctoral Student in Nursing, Universidade Federal do Rio Grande, RS, Brazil. Assistant Professor, Universidade Federal do Pampa, Uruguaiana, RS, Brazil. E-mail: paulafigueiredo@furg.br.

${ }^{2}$ RN, Ph.D. in Nursing, Associate Professor, Escola de Enfermagem, Universidade Federal do Rio Grande, RS, Brazil. E-mail: Wilson lunardifilho@terra.com.br, Valéria - vlunardi@terra.com.br.

${ }^{3}$ RN, Master's Student in Nursing, Universidade Federal do Rio Grande, RS, Brazil. Scholarship holder from Coordenação de Aperfeiçoamento de Pessoal de Nível Superior (CAPES). E-mail: fhernandapimpao@yahoo.com.br.
}

Corresponding Author:

Paula Pereira de Figueiredo

Universidade Federal do Rio Grande. Escola de Enfermagem

Rua General Osório, s/n

Centro

CEP: 96200-000, Rio Grande, RS, Brasil

E-mail: paulafigueiredo@furg.br 


\title{
Mortalidade infantil e pré-natal: contribuições da clínica à luz de Canguilhem e Foucault
}

Neste estudo de revisão objetivou-se verificar como pesquisas realizadas no Brasil relacionam a mortalidade infantil e o pré-natal e apresentar contribuições da clínica à luz de Canguilhem e Foucault, para a qualificação da assistência. Realizou-se revisão integrativa de literatura a partir de buscas nas bases de dados SciELO, LILACS, MEDLINE e BDENF, no período de 2000 a 2009. A relação entre a mortalidade infantil e o pré-natal refere-se ao número insuficiente de consultas ou à qualidade do atendimento prestado. Mesmo quando o número e a rotina de consultas no pré-natal foram adequados, os óbitos evitáveis estiveram presentes. Para a qualificação da assistência oferecida, sugere-se que sejam considerados o conhecimento clínico e os demais elementos componentes do processo de viver humano, no intuito de que o olhar clínico seja ampliado e articulado às tecnologias disponíveis no sistema de saúde e, em conjunto, consigam contribuir para a redução da mortalidade infantil no Brasil.

Descritores: Mortalidade Infantil; Assistência Pré-Natal; Competência Clínica; Enfermagem.

\section{Mortalidad infantil y prenatal: contribuciones de la clínica bajo la perspectiva de Canguilhem y Foucault}

\begin{abstract}
Este estudio de revisión tuvo por objetivo verificar cómo investigaciones realizadas en Brasil relacionan la mortalidad infantil y el prenatal, y presentar contribuciones de la clínica bajo el marco teórico de Canguilhem y Foucault para la calificación de la asistencia. Se realizó una revisión integradora de la literatura a partir de búsquedas en las bases de datos SciELO, LILACS, MEDLINE y BDENF, en el período de 2000 a 2009. La relación entre la mortalidad infantil y el prenatal se refiere al número insuficiente de consultas o a la calidad de la atención prestada. Mismo cuando el número y la rutina de consultas en el prenatal fueron adecuadas, las muertes evitables estuvieron presentes. Para la calificación de la asistencia ofrecida, se sugiere que sean considerados el conocimiento clínico y los demás elementos componentes del proceso del vivir humano, con la intención de que la perspectiva clínica sea ampliada y articulada a las tecnologías disponibles en el sistema de salud $y$, en conjunto, consigan contribuir para la reducción de la mortalidad infantil en Brasil.
\end{abstract}

Descriptores: Mortalidad Infantil; Atención Prenatal; Competencia Clínica; Enfermería.

\section{Introduction}

Infant mortality constitutes an important indicator of the living conditions of a population, it reveals the organization and management of the health services beyond the binomial mother-child care, since it denotes the other socio-environmental factors implicated in the health-disease process. Among them, the educational level of the population, the per capita income and the access to health services can be highlighted(1).

In 2000, the United Nations (UN), when analyzing the major world problems, established eight Millennium Development Goals, with the reduction of infant mortality being Millennium Development Goal 4 (MDG 4 ), which aims to reduce by $2 / 3$ the global rate of infant mortality, between 1990 and 2015(2). With regard to Brazil, an advance in the reduction of infant mortality has been seen in recent years, which may be related, in part, to the commitment of its managers to achieving the Millennium Development Goals. However, this still requires a great effort, since, for example, the Infant Mortality Rate (IMR) in Brazil, in 2009, surpassed that of developed countries in the late 1960s and was approximately three to six times higher than that of 
countries such as Japan, Canada, Cuba, Chile and Costa Rica, in 2007(2-3). From this perspective, the number of infant deaths is considered high and incompatible with the development of the country, demonstrating the existence of serious problems to overcome, for example, the constant regional disparities. Such disparities in health, may be associated with social characteristics of the mother and child (age, race/ethnicity, income and education); with the individual characteristics of the mother (knowledge, attitudes, beliefs and health practices) and with the health services (access, quality of care, type of service) $)^{(3-4)}$.

With regard to the health services, prenatal care presents itself as the main impact factor for the determination of infant mortality, even when socioeconomic conditions (existence of bathroom in the home, access to clean water, residence in rural areas, age and nutritional status of the mother) are favorable ${ }^{(5)}$. Concerning the professional care, it is understood that prenatal care should be provided by a multidisciplinary health team and can be performed by a physician or nurse, as well as other professionals. For this, the professionals in question need to use clinical knowledge related to their professional competence, in order to provide a higher quality of care to the mother-child binomial. The care, in turn, should include both clinical knowledge guided by anatomical and physiological issues and the implementation of hard technologies and the extended clinic. The latter adds to the object of intervention the situations which lead to or increase the risk or the vulnerability to illness, so that it considers, also and especially, the subjects, since it is from them and/or in them that the problems are identified ${ }^{(6)}$. Thus, qualified listening, the consideration of the singularity of the subjects, and the responsibility and ethical commitment of the health workers to the patients constitute characteristics that permeate the extended $\operatorname{clinic}^{(7)}$.

The works of Foucault ${ }^{(8)}$ and Canguilhem ${ }^{(9)}$ approach the extended concept, and also see in the clinic the possibility of considering contextual aspects that interfere in the health/disease process. Foucault( ${ }^{(8)}$, by critically relating the history of the clinic, opens a space to perfect it, recovering aspects that are not necessarily located in space and anatomically in the diseased body. Canguilhem( ${ }^{(9)}$ allows such an approach, while simultaneously highlighting the importance of considering the opinion of the subject in relation to their health status, according to their individuality and through observing their behavior. Therefore, concepts such as normal, standard and normative are used to clarify that health can vary according to each subject, depending on the social and cultural environment in which they are inserted and on their adaptation to adverse living conditions, since the performance of their functions and activities is preserved.

Based on this, the present review study aimed to evaluate research conducted in Brazil related to infant and prenatal mortality and to present contributions of the clinic in the light of Canguilhem ${ }^{(9)}$ and Foucault( ${ }^{(8)}$, directed towards the qualification of the care. This is justified by the fact that the analysis of infant mortality usually does not include the qualitative and philosophical perspective of prenatal care, which may also be relevant to health practice, especially for nurses and physicians who work directly with the management.

\section{Methodology}

The present study is characterized as an Integrative Literature Review, a method that provides a more detailed comprehension of a specific problem, where the purpose is to gather and synthesize results of research on a given theme, in a systematic and ordered way ${ }^{(10)}$. In developing the integrative review, some steps proposed by the author have been taken, considered a reference in this study ${ }^{(10)}$. The first consisted of identifying the theme and the selection of the research questions: What is the relationship between prenatal care and infant mortality? How can the contribution of the clinic of Foucault and Canguilhem be used to qualify the care?

The second step included the establishment of the inclusion and exclusion criteria for studies, samples and the literature search. It should be noted that the search and the selection of the articles included in the review were conducted independently by two reviewers ${ }^{(10)}$. The search for texts was performed through BIREME, in the following databases: Scientific Electronic Library Online (SciELO), Latin American Health Science Literature (LILACS), Medical Literature Analysis and Retrieval System Online (MEDLINE) and the Nursing Database (BDENF), based on the keywords "Infant Mortality" and "Prenatal care", limited to the period from 2000 to 2009. The search was conducted in February 2010. The search had the following inclusion criteria: a) texts derived from research; b) published in national journals in Portuguese, English or Spanish, which were complete, allowing the entire content to be read, excluding theses, dissertations and documents organized by government agencies, such as the Ministry of Health and the World Health 
Organization. The choice of texts published in national journals constituted a methodological strategy for the retrieval of studies carried out exclusively in Brazil. The choice was justified by the search for aspects that reflect the prenatal care performed in the country and that are implicated directly in the infant mortality rate, so that, later, a discussion could be developed, considering the Brazilian reality. In the first search of the databases, 27 articles were encountered, with those repeated being counted only once. In addition, those that did not meet the aims of the study were excluded, resulting in a final sample of nineteen articles, distributed as follows: one article in BDENF, six in MEDLINE, nine in LILACS and three in SciELO.

The third step of the integrative review was to define the information extracted from the selected studies, using an instrument to gather and synthesize the key information $^{(10)}$. The instrument contained items such as: the number of the text; the title; the journal in which it was published; the year of publication; the author; the aim of the study; the methodological approach; the type of study; the characteristics of the sample; the data collection; the data analysis; the outcomes related to prenatal care; the results related to infant mortality; the relationship between prenatal care and infant mortality; and the limitations and suggestions highlighted by the authors.
In the following step, the evaluation of the studies was conducted, which equates to an analysis of the data in a conventional study, in which the use of appropriate tools $\operatorname{occurs}^{(10)}$. The step in question included the evaluation of the studies with regard to the aim of the present review. The fifth and final step of the integrative review corresponded to the discussion of the main search results phase, using Canguilhem ${ }^{(9)}$ and Foucault( ${ }^{(8)}$ as references. Thus, based on the results of the critical evaluation of the included studies, the comparison with theoretical knowledge and the identification of conclusions and implications arising from the integrative review were carried out.

\section{Results}

The presentation of the results was divided into two steps: the first refers to the characterization of the studies that formed the corpus of analysis and the second, refers to the relationship found in the literature between infant mortality and prenatal care. Although the search of the texts was directly related to prenatal care, those selected for analysis focused on the correlation between prenatal care and infant mortality, among the other factors investigated. Figure 1 presents a synthesis of the articles investigated according to the author, the year of publication, the aim and the characteristics of the sample.

\begin{tabular}{|c|c|c|}
\hline Author/Year & AIM & Characteristics of the sample \\
\hline Poles; Parada (2000)(11) & $\begin{array}{l}\text { To identify the causes and the rate of neonatal mortality } \\
\text { during } 1998 \text { in Botucatu/SP. }\end{array}$ & $\begin{array}{l}16 \text { mothers (in their absence, close relatives who } \\
\text { were in attendance). }\end{array}$ \\
\hline Poles; Parada (2002) $)^{(12)}$ & $\begin{array}{l}\text { To identify the causes of infant mortality in } 1998 \text { in Botucatu/ } \\
\text { SP, in order to provide support to the municipal health } \\
\text { services for the planning of their activities related to children } \\
\text { under one year of age. }\end{array}$ & $\begin{array}{l}23 \text { mothers (in their absence, close relatives who } \\
\text { were in attendance). }\end{array}$ \\
\hline $\begin{array}{l}\text { Lansky; França; Leal } \\
(2002)^{(13)}\end{array}$ & $\begin{array}{l}\text { To evaluate the quality of perinatal care, using perinatal } \\
\text { mortality as an indicator of the result of this care in Belo } \\
\text { Horizonte. }\end{array}$ & $\begin{array}{l}826 \text { perinatal deaths, in } 2009 \text {, of residents of the } \\
\text { city of Belo Horizonte. }\end{array}$ \\
\hline $\begin{array}{l}\text { Silva; Andrade; Thomson } \\
(2002)^{(14)}\end{array}$ & $\begin{array}{l}\text { To know the opinions of mothers of children under one year } \\
\text { who died in } 1997 \text { in Londrina, regarding the health services } \\
\text { used, and to demonstrate the feasibility and usefulness of } \\
\text { health service user satisfaction studies. }\end{array}$ & $\begin{array}{l}103 \text { mothers of children who died under one year } \\
\text { of age, residents of the city of Londrina. }\end{array}$ \\
\hline $\begin{array}{l}\text { Saraceni; Leal } \\
(2003)^{(15)}\end{array}$ & $\begin{array}{l}\text { An evaluation of the effectiveness of the campaigns, making } \\
\text { use of the segment of pregnant women identified with } \\
\text { syphilis during the campaigns, through the health information } \\
\text { systems (SINASC, SIM and SINAN), using the comparison } \\
\text { between this group and a control group of pregnant women } \\
\text { not involved in the campaign. }\end{array}$ & $\begin{array}{l}\text { Pregnant women with positive results from the } \\
\text { rapid tests for syphilis. }\end{array}$ \\
\hline $\begin{array}{l}\text { Simões; Silva; Bettiol; Lamy- } \\
\text { Filho; Tonial; Mochel } \\
(2003)^{(16)}\end{array}$ & $\begin{array}{l}\text { To identify the main socio-economic, demographic, } \\
\text { anthropometric and behavioral characteristics, as well as } \\
\text { perinatal outcomes of pregnancy in adolescence. To know } \\
\text { the types of health services used by pregnant adolescents. }\end{array}$ & $\begin{array}{l}2,429 \text { women, excluding multiple births }(50) \text {, } \\
\text { stillbirth ( } 48) \text { the data ignored the other variables } \\
\text { studied (14). }\end{array}$ \\
\hline
\end{tabular}


(continuation)

\begin{tabular}{|c|c|c|}
\hline Author/Year & AIM & Characteristics of the sample \\
\hline $\begin{array}{l}\text { Kilsztajn; Rossbach; Carmo; } \\
\text { Sugahara } \\
(2003)^{(17)}\end{array}$ & $\begin{array}{l}\text { To describe the historical evolution of the infant mortality } \\
\text { rate and the infant mortality rate for diseases of the perinatal } \\
\text { period and those of neonatal mortality by birth weight } \\
\text { and gestation duration, in order to show their importance, } \\
\text { as well as to analyze the role of the number of prenatal } \\
\text { consultations, among other risk factors. }\end{array}$ & $\begin{array}{l}683,637 \text { live births and } 6,491 \text { deaths from } \\
\text { disorders in the perinatal period, the historical } \\
\text { series from } 1980 \text { to } 2000 \text {, in the state of São } \\
\text { Paulo. }\end{array}$ \\
\hline $\begin{array}{l}\text { Araújo; Tanaka; Madi; Zatti } \\
(2005)^{(18)}\end{array}$ & $\begin{array}{l}\text { To know the causes and variables related to the deaths } \\
\text { of newborns (NB) of a neonatal ICU of reference in the } \\
\text { southern region of Brazil. }\end{array}$ & $\begin{array}{l}\text { Total of } 2,247 \text { neonates admitted to the neonatal } \\
\text { ICU of the HG during the study period. }\end{array}$ \\
\hline $\begin{array}{l}\text { Goulart; Somarriba; Xavier } \\
(2005)^{(19)}\end{array}$ & $\begin{array}{l}\text { To investigate infant death from the perspective of the } \\
\text { mothers. }\end{array}$ & 16 mothers who lost their babies. \\
\hline $\begin{array}{l}\text { Mendes; Olinto; Costa } \\
(2006)^{(20)}\end{array}$ & $\begin{array}{l}\text { To identify risk factors associated with infant mortality and, } \\
\text { specifically, with neonatal mortality. }\end{array}$ & $\begin{array}{l}\text { All live births in the period between } 2001 \text { and } \\
2002 \text { who completed the first year of life and had } \\
\text { completed the Statement of Live Birth, whose } \\
\text { mothers resided in the city of Caxias do Sul; as } \\
\text { well as the deaths which occurred in the same } \\
\text { place and time, among those younger than one } \\
\text { year of age }\end{array}$ \\
\hline $\begin{array}{l}\text { Schoeps et al } \\
(2007)^{(21)}\end{array}$ & To evaluate the risk factors for early neonatal mortality. & $\begin{array}{l}146 \text { early neonatal deaths and } 313 \text { children who } \\
\text { survived the neonatal period, in the southern } \\
\text { region of São Paulo city, in the period from } \\
01 / 08 / 2000 \text { to } 31 / 01 / 2001 \text {. }\end{array}$ \\
\hline $\begin{array}{l}\text { Carvalho; Brito; Matsuo } \\
(2007)^{(22)}\end{array}$ & $\begin{array}{l}\text { To analyze the intra-hospital mortality of the newborns with } \\
\text { very low weight, considering clinical progression and the } \\
\text { factors associated with mortality. }\end{array}$ & $\begin{array}{l}\text { All the newborns weighing between } 500 \mathrm{~g} \text { and } \\
1500 \mathrm{~g} \text {, born in Londrina/PR, from } 01 / 01 / 2002 \text { to } \\
30 / 06 / 2004 \text {, observed from birth until discharge } \\
\text { or death in the hospital. }\end{array}$ \\
\hline $\begin{array}{l}\text { Aquino; Guimarães; Sarinho; } \\
\text { Ferreira }(2007)^{(23)}\end{array}$ & $\begin{array}{l}\text { To analyze the risk factors associated with perinatal } \\
\text { mortality in Recife, Pernambuco, Brazil, } 2003 \text {, according } \\
\text { to a hierarchical model of proximal, intermediate and distal } \\
\text { determinants. }\end{array}$ & $\begin{array}{l}283 \text { perinatal deaths which occurred in } 2003 \text {, with } \\
\text { birth weights less than or equal to } 500 \mathrm{~g} \text {, of single } \\
\text { pregnancy residents in the city of Recife, not } \\
\text { suffering from anencephaly. }\end{array}$ \\
\hline $\begin{array}{l}\text { Ventura; Puccini; Silva; Silva; } \\
\text { Oliveira } \\
(2008)^{(24)}\end{array}$ & $\begin{array}{l}\text { To analyze the expression of vulnerability and consequent } \\
\text { differences in access to health services and the occurrence } \\
\text { of deaths in children under one year in the municipality of } \\
\text { Embu. }\end{array}$ & $\begin{array}{l}\text { Data originated from the death certificates and } \\
\text { from the families of children who died before } \\
\text { reaching one year, in } 1996 \text { and 1997, residents in } \\
\text { the municipality of Embu. }\end{array}$ \\
\hline $\begin{array}{l}\text { Matijasevich; et al } \\
(2008)^{(25)}\end{array}$ & $\begin{array}{l}\text { To analyze trends and differences in perinatal mortality over } \\
\text { the period } 1982 \text { to } 2004 \text {. }\end{array}$ & $\begin{array}{l}\text { Data from three cohort studies, which included } \\
\text { all births in the city of Pelotas in the years } 1982, \\
1993 \text { and } 2004 .\end{array}$ \\
\hline $\begin{array}{l}\text { Jobim; Aerts } \\
(2008)^{(26)}\end{array}$ & $\begin{array}{l}\text { To investigate the association between the categories } \\
\text { avoidable and non-avoidable deaths from the classification } \\
\text { of Ortiz and the socio-demographic, reproductive and } \\
\text { maternal variables related to the birth conditions of the child. }\end{array}$ & $\begin{array}{l}1,139 \text { deaths of children under one year of age in } \\
\text { the population of residents of Porto Alegre, which } \\
\text { occurred during the period } 2000 \text { to } 2003 \text {. }\end{array}$ \\
\hline $\begin{array}{l}\text { Nascimento; Costa; Mota; } \\
\text { Paim } \\
(2008)^{(27)}\end{array}$ & $\begin{array}{l}\text { To identify possible risk factors for death in children under } \\
\text { one year in Salvador. }\end{array}$ & $\begin{array}{l}\text { All live births in } 2000 \text {, whose mothers resided } \\
\text { in Salvador, constituting } 1,016 \text { cases and } 2,032 \\
\text { controls. }\end{array}$ \\
\hline $\begin{array}{l}\text { Almeida; Guinsburg; } \\
\text { Martinez; Procianoy; Leone; } \\
\text { Marba; Rugolo; Luz; Lopes } \\
(2008)^{(28)}\end{array}$ & $\begin{array}{l}\text { To evaluate the perinatal factors associated with early } \\
\text { neonatal death in preterm infants with birth weights between } \\
400 \mathrm{~g} \text { and } 1500 \mathrm{~g} \text {. }\end{array}$ & $\begin{array}{l}\text { Live births with gestational age of } 23 \text { to } 33 \\
\text { weeks and weight of } 400 \text { to } 1500 \mathrm{~g} \text { without } \\
\text { malformations, in public tertiary university } \\
\text { maternity wards, between June } 2004 \text { and May } \\
2005 \text {, located in five cities of three Brazilian } \\
\text { states. }\end{array}$ \\
\hline $\begin{array}{l}\text { Nabhan; Oliveira } \\
(2009)^{(29)}\end{array}$ & $\begin{array}{l}\text { To characterize the infant deaths, according to the variables } \\
\text { related to the child, the mother and the care. }\end{array}$ & $\begin{array}{l}\text { Children under one year born alive who died in } \\
\text { the municipality of Cianorte, Paraná state, from } \\
1999 \text { to } 2006 \text {. }\end{array}$ \\
\hline
\end{tabular}

Figure 1 - Synthesis of the articles investigated according to the author, the year of publication, the aim and the characteristics of the sample. 
Of the nineteen selected publications, there was the emergence of a greater number of articles in the Cadernos de Saúde Pública, which produced eight studies; followed by the Revista de Saúde Pública, which published five articles. Regarding the Methodological framework, the predominance of descriptive studies was identified. The existence of one study with a quantitative approach was also registered. It was found that some studies used more than one method of data collection, enabling the complementation of the information. Therefore, the data sources that stood out were, the medical records of the mother and/or the newborn, the health information systems, especially the National System of Mortality (SIM), the Information System on Live Births (SINASC) and the Notification System for Notifiable Diseases (SINAN), as well as regional databases, such as those of the Fundação Seade, of São Paulo, and of semi-structured interviews.

To complete the characterization of the corpus included in the proposed integrative review, it is equally interesting to note the main methods of data analysis used by the authors of the texts. Given the aim of the studies and the quantitative approach of the majority, univariate and multivariate analyses prevailed, with the application of tests such as the test and the two-tailed $\chi^{2}$ test, as well as logistic regression. The results obtained by the studies of infant mortality and its relationship with prenatal care are presented below.

\section{Relationship existing between infant mortality and prenatal care}

The relationship between infant mortality and prenatal care, established in the studies, refers to the insufficient number of consultations ${ }^{(20,25,27)}$ or to the quality of care provided(24-25). Both factors converge for the death in the early days of life of the child, usually related to preventable causes. Some maternal conditions, namely hypertension, preeclampsia, eclampsia, infections, urinary tract infection, hemorrhage, anemia, and gestational age less than 37 weeks, emerge as contributing factors for prematurity and low birth weight, and consequently to neonatal and infant death. However, the studies show that the deaths that occurred could have been reduced by means of appropriate control of the pregnancy during prenatal care ${ }^{(11,18,22,27)}$. Following this perspective, a study conducted from 88 deaths registered in the northwest of Paraná state, found that $70.5 \%$ of them were considered preventable and in 69.4\%, the outpatient and hospital care were involved, which could refer, according to the authors, to the need for better organization of the care provided in prenatal and obstetric units of the hospitals(29). The prevalence of low weight and/or prematurity were also related to the prenatal care, noting that the increase in coverage and improved prenatal care made it possible to reduce the prevalence of intrauterine growth retardation, prematurity and the number of live births with low weight, as well as deaths from diseases in the perinatal period ${ }^{(17,25,27)}$.

Even when prenatal care was not the main object of research, it emerged as a factor to be considered for the prevention of perinatal mortality, since it relates strongly to premature birth and to low birth weight children. In this case, it is recommended that, in addition to improving the quality of life of the population (income and education), the guarantee that quality prenatal care is performed must be considered(16,23-24). Therefore, when considering the quality of care, some studies $(11,13-15,19,21,24,27,29)$ draw attention to its weaknesses, among which the flaws that exist in relation to information, to access and to the organization of the prenatal care are highlighted. Additionally, the studies mentioned the precariousness of communication with the physician or the nurse; the inequality in the relationship established; the unsatisfied need for medication use and other technologies, and especially the lack of commitment of the professionals with the prenatal care. Added to this was the lack of care in the prenatal period, medical negligence, and the non-valorization of signs and symptoms reported by pregnant women, such as the loss of amniotic fluid, increased maternal arterial pressure and the presence of urinary infection, which are possibly implicated in the premature birth of the baby(19).

According to what was mentioned, the negative effect of inadequate or absent prenatal care on early neonatal mortality may be due to the non-detection and the consequent lack of treatment of adverse conditions during the pregnancy. In addition to the number of consultations performed, early initiation of the prenatal care, in the first quarter, requests for routine examinations and the care given to the mother-child binomial are considered important for the reduction of deaths ${ }^{(21)}$. Following the perspective of identifying maternal diseases during the prenatal care, the realization of campaigns for the detection of syphilis, in the municipality of Rio de Janeiro, drew the attention of health professionals to the fact that the acts of the routine of prenatal care were not resolving the problem of congenital syphilis, in the services investigated $^{(15)}$. 
In addition to the aspects highlighted in the literature so far, the fragility of prenatal care at the end of pregnancy was also identified, with the antepartum deaths of infants weighing more than $2500 \mathrm{~g}$ showing a direct relationship with this care. In the case cited, it was found that the quality of care needed to be evaluated, as well as the existence of undesirable practices, such as "prenatal hospitalization", without providing continuity of care to pregnant women, up to the moment of the birth $^{(13)}$. When the opinion of mothers of children under one year who died in London was investigated, the prevalence was observed of negative aspects, related to the care received, which highlights technical and guidance issues. The problems in the organization of the care appeared in second place, with emphasis on complaints regarding the delay in treatment and the difficulty for booking appointments and prenatal consultations $^{(14)}$.

In contrast to these findings, one study ${ }^{(11)}$ on neonatal mortality showed that, even with the realization of early initiated prenatal care and an adequate number of consultations, with the completion of routine laboratory examinations and ultrasound, there still exists the possibility of an unfavorable outcome of the pregnancy. This shows that a good numerical coverage of the prenatal care alone does not guarantee the provision of quality care ${ }^{(11,24,26)}$. Thus, even when there is no statistically significant association between avoidable deaths and prenatal care, situations such as low maternal education, presence of children stillborn, and cesarean section, considered as risk factors for infant mortality, are identified as subject to intervention through qualified care to the mother-child binomial(26). Therefore, the amplification of the access and of the quality of prenatal care can have a positive impact on reducing early neonatal mortality, stressing that the search for information about previous low weight births and indicators of domestic violence, among other risk factors, may offer more adequate conditions for the monitoring of the pregnant women ${ }^{(21)}$.

\section{Discussion}

The studies summarized in the integrative literature review highlight, above all, weaknesses in the quality of the prenatal care, because, even when the texts referred to the quantity of consultations performed during the pregnancy, the authors commonly indicated the need for qualification of the care as a strategy for reducing infant mortality. Conversely, the approach to the qualification proved to be superficial, in that it did not problematize nor suggest how the required qualification could happen and what, exactly, it would be related to. Some aspects can be highlighted, including the change in the work organization in the healthcare services in order to improve the access conditions of pregnant women to the care, which involves the review of the early detection routines; in the scheduling of the consultations and in the reduction of the time of waiting to be attended. As well as the aspects listed, the lack of commitment of the professionals and their difficulties in communication with the pregnant women were also evidenced.

The issues raised permeate the concept of clinic adopted in the present study, which criticizes the standard way that healthcare is often conducted, not considering the severity and/or the needs of individuals, through a professional attitude characterized by remoteness, fixation on standardized technical procedures, difficulty in listening to the complaints and the impossibility of establishing communication beyond the automatic sequence of procedures(30). Additionally, it identifies the relevance of a broader approach by the clinic, in view of the manifestations of dissatisfaction of the women with regard to technical issues and guidance during the prenatal care; to the non-valorization of signs and symptoms reported by them; and to the evidence of preventable diseases such as those responsible for infant mortality.

The persistence of infant deaths attributed to preventable causes, even with the execution of the established routines for adequate and satisfactory prenatal numerical coverage of the care, supports the emphasis on clinical knowledge as an object for further discussion in the present text. To this end, it becomes relevant to make some considerations about the clinical view, from the statement that "in the clinic, what is manifested is originally what is spoken"(8). Thus, it is understood that the language spoken in the clinic relates to the manifestations referred to as pathological by the individual seeking the healthcare service, due to the abnormal manifestations of their body. This corroborates, therefore, the following statement: "in the final analysis, it is the patients who most often decide, and from very different points of view, whether they are no longer normal or whether they have returned to normality"(9). However, "the practicing physician is very often happy to agree with his patients in defining the normal and abnormal according to their individual norms"(9), which leads to a proximity with the results found in the integrative review, in which appears the non-valorization of the 
complaints of pregnant women by the professionals who perform the prenatal care. In this respect, one aspect that may contribute to the classification of prenatal care is emphasized: the consideration of the perception of the pregnant woman about her own health or disease status. It is considered that no one is better than her to define and identify changes in the functioning of her own body, as it is from what these reported changes represent in the development of their activities of daily living, i.e. their normativity, that it is really possible to define their normal or pathological condition. Moreover, the valorization of the complaint goes beyond the clinical observation of the signs and symptoms and the detailed study of the information in conjunction with the pregnant woman, thus, making the expressible visible. This means to materialize what was reported in a series of manifestations likely to define a particular clinical condition and consequently to employ the appropriate therapy for the case.

Since the clinical practice depends on the need to know how to identify the manifestations that deviate from the norm, that is, the pre-established parameters of normality, observation is considered to be one of the methods that should be used more in the care for pregnant women. Observation here is understood as "the art of being in relation with relevant circumstances, of receiving impressions from objects as they are offered to us, and of deriving inductions from them that are their correct consequences"(8). Following this perspective, clinical observation implies the organization of two combined domains: the hospital and the pedagogic ${ }^{(8)}$. As regards the first, it is suggested the individual be removed from their natural, or family environment, so that the pathological fact can be observed in its singularity of occurrence. This is justified by the fact that the hospital domain allows a homogeneous neutrality for the clinical observation of signs and symptoms, particularly due to the possibility of systematic monitoring of the patient, without external interferences that would change their condition. This would lead to the analysis of the truth and put to the side the factors extrinsic to the illness. However, for the qualification of the prenatal care, the clinical view must turn to the pregnant woman, in the areas of family and community. Thus, a bond would be formed with the woman, which would promote the continuous and longitudinal monitoring of the pregnancy, attending to the same principles of the hospital domain, since this would capture the most diverse pathological manifestations the mother-child binomial are subject to, the changes, repercussions and consequences for the well being of both.
The previous obstetric history of the woman, the investigation of the birth of underweight babies in other pregnancies, and the presence of domestic violence during the pregnancy were factors identified in the literature consulted and appear as elements to be observed in the meetings between the pregnant woman and the healthcare professional. The extended approach is consistent with the perspective that "Man, even physical man, is not limited to his organism. Having extended his organs by means of tools, man sees in his body only the means to all possible means of action. Thus, in order to discern what is normal or pathological for the body itself, one must look beyond the body"(9). Thus, the violence and the social aspects that influence the disease process also represent risk factors for infant mortality and need to be well explored during the prenatal care, so that they can be identified and considered in the establishment of the therapeutics applied to each of the individuals, comprehended here as the mother-child binomial.

The issues raised are directed toward a broader conception of the clinic, where the focus of care is modified, in order to extend the biological paradigm to the subjectivity of the subjects. This provides a way to overcome the clinical view of the normal and pathological, and to lead it to other points/topics that may equally influence the determination of the health/ disease process $^{(6)}$. While achieving this, it is confirmed that the clinic assumes the responsibility to discover secrets, i.e. goes beyond what is visible. Nevertheless, for its exercise sagacity, attention, accuracy, dexterity and patience are necessary, only then can the clinical view articulate what was said and what is said(8).

Finally, there is a need to discuss the qualification of the prenatal care, even for those women who perform the appropriate number of consultations, because, according to the literature, they also present problems and their pregnancies can be subject to unfavorable outcomes. It is necessary to consider that the actions of the prenatal care routine present weaknesses in the identification and in the treatment of preventable diseases, such as congenital syphilis, arterial hypertension, preeclampsia and eclampsia, urinary infection and other maternal infections. For these reasons, the attentive view of the health professionals regarding clinical knowledge is recommended, a practice that has proved to be a potential work instrument, which can enable differentiated care to the pregnant woman and her baby. From the perspective of the analysis, it must be understood that the number of consultations 
and the attendance of the prenatal examination routine do not guarantee the qualification of the care. It is not enough to have access to healthcare services and to examinations; it is necessary that the professionals responsible for the care have and use the clinical knowledge, because it will provide the support necessary for intervention in adverse situations, contributing to the reduction of infant mortality.

In other words, "if the microscope is capable of serving clinical practice, it is up to clinical practice to enlighten the microscope"(9). This means that the latest generation of equipment and examinations, alone, are not synonymous with good care, if there is not a healthcare professional behind them with sufficient clinical knowledge to make the interpretation of the results. Furthermore, "A microscope, a thermometer, a culture medium knows no medicine which the physician would not know. They give a result. This result has no diagnostic value in itself. In order to reach a diagnosis, the sick persons behavior must be observed"(9).

\section{Final considerations}

Infant mortality was related to the prenatal care in the different studies undertaken in Brazil, focusing on either the insufficient number of consultations, or the quality of the care provided. However, even when the number and routine of prenatal care consultations were adequate, avoidable deaths were present, showing that not only the quantitative aspects and the routine need to be addressed, but also the quality of the care needs to be revised. Although several studies recognize these weaknesses in the care, the authors did not suggest ways to qualify the prenatal care. From the same literature investigated, it was not possible to reflect on the clinical knowledge as a potential instrument for the organization of nursing work and of healthcare, which was made possible by the expanded discussion of the clinic in the light of Canguilhem and Foucault, in this study. Therefore, from a brief resume of the concepts of normal and pathological and of integrated elements of the history of the clinic, it is hoped that the discussion carried out can contribute to change the focus of pregnancy to the pregnant woman. This does not mean disregarding the clinical and biological aspects present during pregnancy, but includes the consideration of the women in her singularity and subjectivity, without losing sight of her insertion in a social context.

Contrary to the history of the clinic and considering the technological support currently available, it cannot be allowed that, even today, many children die in our country. It is therefore necessary to explore and consolidate the existing clinical knowledge and direct it in favor of life. Thus, it is suggested that, for the qualification of prenatal care, the clinical knowledge and other elements that comprise the process of human living are taken into consideration, in order that the clinical view is expanded and articulated to the technologies available in the health system and that, together, they may be able to contribute to the reduction of infant mortality in Brazil.

\section{References}

1. Chan MF, NG WI, Van IK. Socioeconomic instability and the availability of health resources: their effects on infant mortality rates in Macau from 1957-2006. [Cultural perspectives]. ] Clin Nurs. 2009;19:884-91.

2. UNICEF. Situação mundial da infância 2009: saúde materna e neonatal. [Internet]. [acesso 7 ago 2010]. Disponível em: http://www.unicef.pt/docs/situacao_ mundial_da_infancia_2009.pdf.

3. Ministério da Saúde (BR). Manual de vigilância do óbito infantil e fetal e do Comitê do óbito infantil e fetal. Brasília: Editora do Ministério da Saúde; 2009. 77 p.

4. Walker LO, Chesnut LW. Identifying health disparities and social inequities affecting childbearing women and infants. JOGNN. 2010;39:238-338.

5. Hong R, Ruiz-Beltran M. Impact of prenatal care on infant survival in Bangladesh. Matern Child Health J. 2007;11:199-206.

6. Campos GWS. Clínica e Saúde Coletiva compartilhadas: teoria Paideia e reformulação ampliada do trabalho em saúde, 2006. [Internet]. [acesso 2 ago 2010]. Disponível em: http://www.sms.fortaleza.ce.gov.br/sms_v2/ Downloads/05062008_Gastao_Cl\%C2\%A1nica_Saude_ Coletiva_compartilhadas.pdf

7. Ministério da Saúde (BR). HumanizaSUS: A clínica ampliada. Brasília: Editora do Ministério da Saúde 2004. $18 \mathrm{p}$.

8. Foucault M. O nascimento da clínica. Rio de Janeiro: Forense-Universitária; 1977.

9. Canguilhem G. O normal e o patológico. Rio de Janeiro: Forense-Universitária; 1978.

10. Whittemore R. Combining evidence in nursing research: methods and implications. Nurs Res. 2005. Jan-Feb;54(1):56-62.

11. Poles K, Parada CMG L. Mortalidade neonatal em 1998, no município de Botucatu - São Paulo. Rev. Latino Am. Enfermagem. 2000;8(3):67-75. 
12. Poles K, Parada CMGL. Mortalidade infantil em município do interior do Estado de São Paulo. Rev Esc Enferm USP. 2002;36(1):10-7.

13. Lansky S, França $E$, Leal MC. Mortes perinatais evitáveis em Belo Horizonte, Minas Gerais, Brasil, 1999. Cad Saúde Pública. 2002;18(5):1389-400.

14. Silva AMR, Andrade SM, Thomson Z. Opiniões de mães de crianças que morreram no primeiro ano de vida no município de Londrina, Paraná, Brasil. Cad Saúde Pública. out 2002;18(5):1295-302.

15. Saraceni V, Leal MC. Avaliação da efetividade das campanhas para eliminação da sífilis congênita na redução da morbimortalidade perinatal, município do Rio de Janeiro, 1999-2000. Cad Saúde Pública. set-out 2003;19(5):1341-9.

16. Simões VMF, Silva AAM, Bettiol H, Lamy-Filho F, Tonial SR, Mochel EG. Características da gravidez na adolescência em São Luís, Maranhão. Rev Saúde Pública. 2003;37(5):559-65.

17. Kilsztajin S, Rossbach A, Carmo MSN; Sugahara GTL. Assistência pré-natal, baixo peso ao nascer e prematuridade no estado de São Paulo, 2000. Rev Saúde Pública. 2003;37:303-10.

18. Araújo BF, Tanaka ACA, Madi JM, Zatti H. Estudo da mortalidade de recém-nascidos internados na UTI neonatal do Hospital Geral de Caxias do Sul, Rio Grande do Sul. Rev Bras Saúde Materno Infantil. out-dez $2005 ; 5(4): 463-9$.

19. Goulart LMHF, Somarriba MG, Xavier CC. A perspectiva das mães sobre o óbito infantil: uma investigação além dos números. Cad Saúde Pública. mai-jun 2005;21(3):715-23.

20. Mendes KG, Olinto MTA, Costa JSB. Case-control study on infant mortality in southern Brazil. Rev Saúde Pública. 2006;40(2):240-8.

21. Schoeps D, Almeida MF de, Alencar GP de, França I Jr, Novaes HMD, Siqueira AAF de, et al. Fatores de risco para mortalidade neonatal precoce. Rev Saúde Pública. 2007;41(6):1013-22.

22. Carvalho ABR, Brito ASJ, Matsuo T. Assistência à saúde e mortalidade de recém-nascidos de muito baixo peso. Rev Saúde Pública. 2007;41(6):1003-12.

23. Aquino TA, Guimarães MJB, Sarinho SW, Ferreira LOC. Fatores de risco para a mortalidade perinatal no Recife, Pernambuco, Brasil, 2003. Cad Saúde Pública. dez 2007;23(12):2853-61.

24. Ventura RN, Puccini RF, Silva NN, Silva EMK, Oliveira

EM. The expression of vulnerability through infant mortality in the municipality of Embu. São Paulo Med J. 2008;126(5):262-8.
25. Matijasevich $A$, Santos IS, Barros AJD, Menezes AMB, Albernaz EP, Barros FC, et al. Perinatal mortality in three population-based cohorts from Southern Brazil: trends and differences. Cad Saúde Pública. 2008;24 Sup 3:5399-408.

26. Jobim R, Aerts D. Mortalidade infantil evitável e fatores associados em Porto Alegre, Rio Grande do Sul, Brasil, 2000-2003. Cad Saúde Pública. jan 2008;24(1):179-87.

27. Nascimento EMR, Costa MCN, Mota ELA, Paim JS. Estudo dos fatores de risco para óbitos de menores de um ano mediante compartilhamento de bancos de dados. Cad Saúde Pública. 2008;24(1):2593-602.

28. Almeida MFB, Guinsburg R, Martinez FE, Procianoy RS, Leone CR, Marba STM, et al. Perinatal factors associated with early deaths of preterm infants born in Brazil Network on Neonatal Research centers. J Pediatr. 2008;84(4):300-7.

29. Nabhan SS, Oliveira RZ. Óbitos infantis, características maternas e de assistência em município da região noroeste do Paraná, Brasil, 1999 a 2006. Acta Scientiarum Health Sci. 2009;31(1):71-6.

30. Campos GWS. Saúde Paideia. $3^{a}$ ed. São Paulo: Hucitec; 2003.
Received: Jan. 12 2011 Accepted: Oct. $11^{\text {th }} 2011$ 